\title{
ОСВІТНІЙ ПЕРЕКЛАДАЧ ЖЕСТОВОЇ МОВИ: КАДРОВЕ ЗАБЕЗПЕЧЕННЯ КОМУНІКАТИВ- НИХ ПОТРЕБ ЖЕСТОМОВНИХ ЗДОБУВАЧІВ ОСВІТИ
}

\begin{abstract}
Наталія Адамюк, Інститут спеціальної педагогіки та психології імені Миколи Ярмаченка Національна академія педагогічних наук України, м. Київ, Україна, natbor07@gmail.com
\end{abstract}

Висвітлено значення понять «жестомовні здобувачі освіти» та «освітній перекладач жестової мови». Акцентовано увагу на хибності застосування застарілих термінів «перекладачдактилолог» і «сурдоперекладач».

Розкрито зміст ст. 21 Саламанської декларації стосовно важливості жестової мови як засобу спілкування та доступу осіб із порушеннями слуху до освіти.

Стисло зазначено та обгрунтовано відмінність у подоланні комунікативного бар'єру жестомовними особами у порівнянні 3 чуючими представниками інших національних меншин. Окреслено стратегії забезпечення комунікативних потреб жестомовних осіб під час здобуття ними освіти. Схарактеризовано послуги, що забезпечують адаптацію освітнього середовища до комунікативних потреб жестомовних здобувачів освіти.

Висвітлено вимоги до перекладача жестової мови у освітньому закладі, викладені в Довіднику кваліфікаційних характеристик професій працівників і сформульовані сучасні функції освітнього перекладача жестової мови. Наведено статистичні дані утог щодо кількості таких фахівців у закладах вищої освіти, де навчаються жестомовні особи.

Ключові слова: інклюзивне навчання, перекладач, спеціальна освіта.

Наталия Адамюк, Институт специальной педагогики и психологии имени Николая Ярмаченко НАПН Украины, г. Киев

Образовательный переводчик жестового языка: кадровое обеспечение коммуникативных потребностей жестоязычных соискателей образования

Освещено значение понятий «жестоязычные соискатели образования» и «образовательный переводчик жестового языка». Акцентировано внимание ошибочность применения устаревших терминов «переводчик-дактилолог» и «сурдопереводчик».

Раскрыто содержание ст. 21 Саламанский декларации о важности жестового языка как средства общения и доступа лиц с нарушениями слуха к образованию.

Кратко указано и обосновано отличие в преодолении коммуникативного барьера жестоязычными лицами по сравнению со слышащими представителями других национальных меньшинств. Определены стратегии обеспечения коммуникативных потребностей жестоязычных лиц во время получения ими образования. Охарактеризованы 
услуги, обеспечивающие адаптацию образовательной среды $\mathrm{k}$ коммуникативным потребностям жестоязычных соискателей образования.

Освещены требования к переводчику жестового языка в образовательном учреждении, изложенные в Справочнике квалификационных характеристик профессий работников и сформулированы современные ффунции образовательного переводчика жестового языка. Приведены статистические данные УТОГ по количеству указанных специалистов в учреждениях высшего образования, где обучаются жестоязычные лица.

Ключевые слова: инклюзивное обучение, переводчик, специальное образование.

Natalia Adamiuk, Mykola Yarmachenko Institute of Special Education and Psychology of The National Academy of Educational Sciences of Ukraine, Kyiv, Ukraine

Sign language educational translator: staffing the communicative needs of sign language education applicants

This article highlights the meaning of the new concepts for «sign language learners» and «sign language educational translator» for Ukraine. Attention is focused on the erroneous use of the outdated terms "fingerprint translator" and "sign language interpreter".

The content of Art. 21 of the Salamanca Declaration on the Importance of Sign Language as a Means of Communication and Access for Persons with Hearing Impairments to Education through National Sign Language, both in special schools and in inclusive classes, groups of educational institutions.

Briefly indicated and justifiably the difference in overcoming the communication barrier by sign-speaking people compared with hearing representatives of other national minorities who use only verbal language.

Accordingly, two strategies are outlined to meet the communicative needs of deaf people during their education: modification and adaptation of the educational environment. The services providing adaptation of the educational environment to the communicative needs of deaf learners are characterized.

The requirements for a sign language translator in an educational institution, outlined in the Handbook of qualification characteristics of professions of workers, are outlined and the modern functions of an educational sign language translator are formulated.

Statistical data of the Ukrainian Society of the Deaf are given for the number of relevant specialists in higher education institutions where deaf people who use sign language are trained.

Keywords: inclusive training, translator, special education.

На терені України виклики сьогодення щодо забезпечення комунікативних потреб жестомовних осіб в отриманні повної освіти випереджають фактичну реальність. Дослідженням питання кадрів у частині якісних та кількісних показників займаються сучасні науковці, які досліджують жестову мову з метою ї вивчення відповідними фахівцями у освітній сфері $[3,5]$. Тому, головним завданням статті є розкриття актуальності зазначеної проблематики, а саме висвітлення питання кадрового забезпечення як головного чинника доступності жестомовних осіб до отримання освіти.

Жестомовні здобувачі освіти - це особи, які здобувають освіту і використовують в якості основного або одного з основних засобів спілкування та обміну 
інформацією жестову мову (ЖМ) [6]. Більш конкретно: якщо ЖМ є основним засобом спілкування і отримання інформації, то у разі відсутності цієї мови як засобу навчання ці особи не можуть здобувати якісну освіту. Тобто потреба і право жестомовних осіб на здобуття освіти є не реалізованими, оскільки ЖМ це умова для забезпечення доступності освіти для них.

У cm. 21 Саламанської декларації та рамки дій про принципи, політику та практичну діяльність у галузі освіти осіб з особливими освітніми потребами (1994) зазначено: «Освітня політика повинна повністю враховувати індивідуальні відмінності та особливості. Важливість жестової мови як засобу спілкування осіб із порушеннями слуху має бути визнана й спонукати до відповідних заходів для забезпечення того, щоб усі особи з порушеннями слуху мали доступ до освіти через свою національну жестову мову. 3 огляду на специфічні комунікативні потреби осіб із порушеннями слуху, їх освіту, можливо, доцільніше забезпечувати в спеціальних закладах чи спеціальних класах/групах звичайних закладів освіти». Нами уточнено переклад англомовного тексту Саламанської декларації, оскільки офіційний переклад не точний, бо використовує поняття «мова жестів» замість «жестової мови», «особливі потреби у комунікації» замість «комунікативні потреби», «глухі» замість «особи з порушеннями слуху» (як про це зазначено у сm. 7 ЗУ «Про освіту»). Цей документ пов'язаний із упровадженням інклюзії, утім, саме для жестомовних осіб вказано на доцільність збереження чи створення спеціальних класів і груп, бо засіб їхньої комунікації відрізняється від комунікації більшості здобувачів освіти.

У процесі навчання чуючих дітей, які належать до національних меншин, можна поступово, після опанування ними українською словесною мовою (CM), переходити на навчання даною мовою, -тоді як при навчанні осіб із порушеннями слуху отримати аналогічний результат украй важко. Комунікативні потреби дітей національних меншин можуть змінитися: одна мова може цілком замінити іншу, якщо буде подоланий комунікативний бар'єр, зумовлений незнанням української мови. Щодо жестомовних здобувачів освіти складно повноцінно замінити природне жестове мовлення усним мовленням, оскільки комунікативний бар'єр зумовлений фізичним порушенням слухового аналізатора, і його повноцінно усунути в процесі навчання неможливе. Адже, його всунення можливе лише через зміну не особи, яка користується ЖМ, а освітнього середовища його комунікативної складової. Виокреслюються дві стратегії забезпечення комунікативних потреб жестомовних осіб під час здобуття освіти:

- модифікація освітнього середовища, тобто створення повноцінного двомовного освітнього простору закладу. «Повноцінне двомовне середовище» означає, що безпосередня комунікація з жестомовними особами відбувається через ЖМ, а опосередковане навчання - через читання і письмо. Так, усі, хто оточує зазначену категорію осіб, вільно володіють двома мовами: (CM) і ЖМ. Ця стратегія, переважно, стосується загальноосвітніх спеціальних шкіл для дітей із порушеннями слуху;

- адаптація освітнього середовища шляхом залучення асистента для забезпечення індивідуальних комунікативних потреб здобувача освіти. Ця стратегія

«ОСОБЛИВА ДИТИНА: навчання і виховання», № 4, 2019 
стосується досить широкого кола закладів освіти, які відповідно до законодавства зобов'язані надавати освітні послуги різним категоріям учнів, зокрема й жестомовним особам. Мова йде, насамперед, про інклюзивне освітнє середовище, що відповідає потребам жестомовних здобувачів освіти.

Адаптацію освітнього середовища до комунікативних потреб жестомовних здобувачів освіти забезпечують різні послуги. Для закладів загальної середньої освіти це - індивідуальна програма реабілітації, у якій передбачено потребу в послугах перекладача ЖМ. І це зазначено в проекті Постанови Кабінету Міністрів України «Про затвердження Порядку організації інклюзивного навчання у закладах загальної середньої освіти». Що стосується вищої школи (ПТУ, коледжі, університети), то у cm. 5 Постанови Кабінету Міністрів України «Про затвердження Порядку організації інклюзивного навчання у закладах професійної (професійно-технічної) освіти» та $\mathrm{cm}$. 4. Постанови Кабінету Міністрів України «Про затвердження Порядку організації інклюзивного навчання у закладах вищої освіти» зазначено: «Організація освітнього процесу здобувачів освіти 3 особливими освітніми потребами у закладах... передбачає: застосування в освітньому процесі найбільш прийнятних для здобувачів освіти з особливими освітніми потребами методів і способів спілкування, зокрема української жестової мови..., із залученням відповідних фахівців і педагогічних працівників». Тобто на всіх рівнях освіти: заклади загальної середньої освіти, професійної (професійно-технічної) освіти, заклади вищої освіти, передбачається наявність спеціаліста для забезпечення комунікативних потреб жестомовних осіб. Такими спеціалістами можуть бути або жестомовний асистент (особа, яка вільно володіє ЖМ, але не має освіти за цим профілем), або перекладач ЖМ (фахівець з освітою відповідного профілю). Жестомовні асистенти можуть працювати тільки у разі, коли немає можливості залучити перекладача ЖМ.

Перш, ніж перейти до питання щодо діяльності перекладачів ЖМ у сфері вищої освіти, вважаємо за потрібне надати інформацію стосовно закладів загальної спеціальної середньої освіти. Отже: в 11 загальноосвітніх спеціальних школах 17 педагогів мають посвідчення перекладача ЖМ (Кисляцька, Хустська, Кам'янська. Київські СЗ3СО №№ 6, 9, Миколаївська, Полтавська, Сумська, Херсонська. Хмельницька, Чернігівська). Зазначені посвідчення були отримані педагогічними працівниками після проходження курсів з підготовки перекладачів ЖМ на базі Навчально-відновлювального центру Українського товариства глухих (УТОГ) [4].

Для більш ширшого уявлення висвітлимо дані щодо фахівців, які забезпечують переклад в закладах вищої освіти станом на 2016 р. Точні дані надати неможливо, оскільки в штатних розписах закладів вищої освіти посада перекладача ЖМ (за винятком одиничних випадків) не передбачена. Так:

- в університетах України для забезпечення комунікативних потреб жестомовних здобувачів освіти було задіяно 19 перекладачів ЖМ на 31 заклад, у якому функціонували 3 спеціальні групи жестомовних студентів на основі виділеної МОН України квоти за клопотанням Центрального правління УТОГ, 5 спеціальних груп за клопотанням ЦП УТОГ та 33 особи були охоплені інклюзивним навчанням; 
- у коледжах перекладацькі послуги надавали 22 перекладачі ЖМ на 31 заклад, у якому діяли 3 спеціальні групи студентів на основі виділеної МОН України квоти за клопотанням ЦП УТОГ, 13 спеціальних груп за клопотанням ЦП УТОГ та 15 студентів з порушеннями слуху навчалося інклюзивно;

- у закладах професійної (професійно-технічної) освіти працював 21 перекладач ЖМ на 41 заклад (16 спеціальних груп учнів були створені за клопотанням ЦП УТОГ та 25 глухих студентів навчалися поодинці. Всього у вищій школі (103 заклади) доступ до освіти засобом перекладу ЖМ-СМ забезпечували 62 перекладачі ЖМ [4].

Для розуміння ролі перекладачів ЖМ в освітньому процесі варто звернутися до нормативної бази, а саме до Класифікатора професій України та Довідника кваліфікаційних характеристик професій працівників, у яких зазначена посада «перекладач-дактилолог навчальних закладів» [1, 2]. До його обов'язків відносяться:

1. Синхронний переклад з усної мови на дактильно-жестову і навпаки занять, лекцій, зборів тощо для глухих і працівників.

2. Переклад ділових та побутових особистих розмов між глухими та чуючими особами, консультацій, порад або лекцій спеціалістів.

3. Функція керівника навчальної групи.

4. Розроблення перспективних та поточних планів різних заходів.

5. Вивчення та аналіз інтелектуального рівня глухих.

6. Контроль відвідування, успішності та проходження практики.

7. Ведення документації.

8. Робота над підвищенням своєї кваліфікації, популяризація дактильножестової мови та проводення вивчення цієї мови.

9. Участь у роботі кабінетів мови та читання з губ.

10. Популяризація діяльності громадських організацій глухих.

Звертаємо увагу: переклад має бути не з усної мови, а зі словесної, а остання має усну і писемну форми; дактильна абетка є елементом жестового мовлення, але не ЖМ. Загалом, якщо взяти для прикладу перекладача англійської мови, який працюе в закладі освіти і здійснює переклад, - то до кола його обов'язків не входить керівництво навчальною групою, розроблення планів заходів, контроль відвідування, діагностування інтелектуального рівня англомовних осіб, - оскільки його основною функцією є якісний переклад. Отже, зазначені обов’язки є неприйнятними і для перекладача ЖМ, який працює у закладі освіти.

$\mathrm{У}$ цій статті звертаємо увагу на застосування поряд 3 правильним терміном перекладач ЖМ (визнаний і поширений у світі) неправильно термінів «перекладач-дактилолог» та «сурдоперекладач». Перший термін свідчить, що даний фахівець лише дактилює всі озвучені мовні одиниці СМ, хоча насправді це не так. Другий є неправильним вже тому, що виключає контакт з чуючою особою, адже відомо, що перекладач ЖМ здійснює переклад: 1) зі СМ на ЖМ, де джерелом інформації є чуюча особа і об'єктом їі отримання є глуха особа, 2) із ЖМ на СМ, де джерелом інформації, навпаки, є глуха особа, а об'єктом 
отримання іï є чуюча особа. Отже, перекладач ЖМ працює з двома сторонами: чуючою і глухою [6].

Наразі розглянемо відмінність термінів перекладач ЖМ та освітній перекладач ЖМ, останній з яких є новим для України, утім, поширеним у розвинутих країнах світу. Отже, відмінність полягає у тому, що перекладач ЖМ забезпечує мовні потреби жестомовної особи, а освітній перекладач ЖМ - комунікативні потреби. Освітній перекладач - це рольова мовна модель, часто це особа, яка дисциплінує жестомовних осіб (привертає іх увагу), є моделлю правил поведінки в спільноті чуючих здобувачів освіти. Освітній перекладач - член команди супроводу здобувача освіти. Він знає і дотримується цілей і завдань індивідуальної програми розвитку. Освітній перекладач має володіти не лише природним жестовим мовленням, а й іншими засобами комунікації: дактилюванням, калькованим жестовим мовленням, мануоральною артикуляцією тощо, і застосовувати ці засоби відповідно до потреб дитини та завдань навчання. Саме тому він забезпечує не лише мовні (переклад ЖМ - СМ), а й комунікативні потреби осіб із порушеннями слуху.

Завдання освітнього перекладача ЖМ мають бути такими. Він:

- здійснює прямий переклад усного мовлення (синхронний, послідовний) на ЖМ для осіб з порушенням слуху, які спілкуються ЖМ; здійснює зворотний переклад (синхронний, послідовний) ЖМ на усне мовлення для чуючих;

- здійснює достовірний переклад (прямий і зворотний) на ЖМ особам 3 порушенням слуху та чуючих, забезпечуючи взаєморозуміння між ними;

- забезпечує точну відповідність перекладу СМ на ЖМ за смисловим змістом з дотриманням мовних норм, зокрема, встановлених наукових, технічних та інших термінів і визначень;

- проводить роботу з уточнення перекладу нових термінів, понять і визначень, що зустрічаються в українській мові.

Освітній перекладач ЖМ завжди працює у парі з викладачем, і разом 3 ним він постає мовною моделлю перед жестомовними учнями, студентами. Тому суттєвими є такі моменти:

1) стиль мовлення освітнього перекладача ЖМ має відповідати стилю мовлення викладача, бо освітній перекладач ЖМ - це віддзеркалення викладача. Скільки є викладачів - стільки є стилів мовлення освітнього перекладача ЖМ;

2) глухий студент має знати конкретне мовлення конкретного викладача;

3) освітній перекладач ЖМ своїм мовленням може нівелювати як мовлення викладача, так і його самого. Спотворюють мовну модель такі чинники як: слабке володіння ЖМ; недостатній рівень мовної компетентності; незнання матеріалу, що перекладається; спотворення понять, що подаються викладачем [4].

Ми знаємо, що нормативні документи визначають, що є комунікативні потреби у осіб із порушеннями слуху, а тому існує потреба в освітніх перекладачах ЖМ. Позаяк, переходячи до питання підготовки зазначених фахівців маємо констатувати, що в Україні ніхто не готує освітніх перекладачів ЖМ, тоді як за кордоном їх готують коледжі, інститути, університети. Термін навчання триває впродовж 4-5 років і випускник освітнього закладу отримує диплом перекладача ЖМ 
(зі спеціалізацією в освітній сфері). Обов'язковою вимогою є отримання ним сертифікації (дозволу на роботу в якості перекладача ЖМ в освітніх закладах).

Утім, перекладачі ЖМ в Украйні є. Їхньою підготовкою займається лише одна громадська організація - УТОГ на своїй базі «Навчально-відновлювальний центр УТОГ». Термін навчання на курсах з підготовки перекладачів ЖМ становить 4,5 місяця і слухачі одержують свідоцтво про отримання робітничої професії «перекладач ЖМ», термін на курсах підвищення кваліфікації становить 2 місяці і перекладачі ЖМ одержують свідоцтво про отримання робітничої професії «старший перекладач ЖМ». Сертифікація як така у Товаристві відсутня, натомість, здійснюється атестація 1 раз на 3 роки.

Навчальна програма курсів 3 підготовки перекладачів ЖМ має ліцензію Міністерства освіти і науки України. Вона містить 5 розділів теорії, а саме: «Особливості навчання і виховання осіб із порушеннями слуху» (26 год), «Лінгвістика жестової мови та дактилологія» (58 год), «Жестова мова» (80 год), «Основи ділового етикету» (6 год), «Основи психології та педагогіки» (16 год).

На основі вищевикладеного формулюємо такі висновки:

1. Жестомовний здобувач освіти - це особа, яка для отримання освіти використовує ЖМ як єдиний або однин із основних засобів мовлення.

2. Забезпеченням комунікативних потреб (які на відміну від мовних є глибшими і суттєвими) жестомовних здобувачів освіти мають займатися відповідні фахівці, а саме освітні перекладачі ЖМ. Натомість в освітніх закладах вищої освіти працюють перекладачі ЖМ без відповідної для цього підготовки.

3. Спостерігається відсутність освітніх перекладачів ЖМ у спеціальних школах під час предметного навчання, яке здійснюють викладачі без відповідної мовної освіти.

4. В Україні швидкими темпами відбувається охоплення інклюзивним навчанням осіб з освітніми потребами, утім, відзначаємо недостатню кількість освітніх перекладачів ЖМ в інклюзивних класах/групах закладів освіти на всіх рівнях.

5. Відсутність кадрового забезпечення пояснюється відсутністю підготовки освітніх перекладачів ЖМ на державному рівні. Натомість підготовкою перекладачів ЖМ для роботи у різних сферах діяльності глухих осіб займається лише громадська організація - Українське товариство глухих за єдиною ліцензованою програмою навчання, яке має короткотривалий термін.

6. Для якісної підготовки освітніх перекладачів ЖМ доцільно застосувати досвід зарубіжних країн, де після отримання освітньо-кваліфікаційного рівня «бакалавр» та «магістр» підготовлені фахівці проходять спеціальну сертифікацію та у певний період проходять підвищення кваліфікації освітніх перекладачів ЖМ.

\section{ЛITEPATУPA}

1. Довідник кваліфікаційних характеристик професій працівників. Випуск 80 «оціальні послуги». - Краматорськ: Центр продуктивності, 2005, 117 с.

2. Класифікатор професій. ДК 003 : 2010 / [розробники: М. Гаврицька, В. Глоба, Т. Гречушкіна та ін. ]. - К.: Соцінформ, 2010, 746 с.

«ОСОБЛИВА ДИТИНА: навчання і виховання», № 4, 2019 13 
3. Адамюк Н. Б. До питання про реальний стан навчання інвалідів зі слуху в Україні /Н.Б. Адамюк // Зб. наук. праць VII Міжнародної науково-практичної конференції [Актуальні проблеми навчання та виховання людей з особливими потребами]. (22-23 листопада 2006 р.) - К.: Університет «Україна», 2006. - С. 76 - 84.

4. Адамюк H. Б. Перекладач у навчальному закладі як модель жестової мови для глухих студентів /Н. Б. Адамюк. - Збірник наукових праць «Педагогічні науки». Випуск LXIX. Том 3, Херсон.: Херсонський державний університет, видавничий дім «Гельветика», 2016. C. $7-12$.

5. Адамюк Н. Б. Проблемні аспекти отримання вищої освіти в Україні жестомовними глухими особами /Н. Б. Адамюк. - Збірник наукових праць «Педагогічні науки». Випуск LXXXIII. - Том 1, Херсон. : Херсонський державний університет видавничий дім «Гельветика, 2018. - С.194-202.

6. Адамюк Н. Б. Сучасний погляд на жестову мову / Н. Б. Адамюк. - Освіта осіб з особливими потребами: шляхи розбудови: зб. наук. праць: Вип. 14 / за ред. В. В. Засенка, А. А. Колупаєвої. - 2018. - С.11-20.

\section{REFERENCES (TRANSLATED AND TRANSLITERATED)}

1. Dovidnyk kvalifikatsiinykh kharakterystyk profesii pratsivnykiv. Vypusk $80 \ll$ Sotsialni posluhy». - Kramatorsk: Tsentr produktyvnosti, 2005, 117 s.

2. Klasyfikator profesii. DK $003: 2010$ / [ rozrobnyky: M. Havrytsкa, V. Hloba, T. Hrechushkina ta in. ]. - K.: Sotsinform, 2010, $746 \mathrm{~s}$.

3. Adamiuk N. B. Do pytannia pro realnyi stan navshannia invalidiv zi slukhu v Ukraini /N. B. Adamiuk //Zb. nauk. prats VII Mizhnarodnoi naukovo-praktychnoi konferentsii [Aktualni problelmy navchannia ta vykhovannia liudei z osoblyvymy potrebamy]. (22-23 lystopada 2006 r.) - K.: Universytet «Ukraina», 2006. - S. $76-84$.

4. Adamiuk N. B. Perekladach u navchalnomu zakladi yak model zhestovoi movy dlia hlukhykh studentiv / N. B. Adamiuk. - Zbirnyk naukovykh prats «Pedahohichni nauky». Vypusk LXIX. Tom 3, Kherson.: Khersonskyi derzhavnyi universytet, vydavnychyi dim «Helvetyka», 2016. S.7-12.

5. Adamiuk N. B. Problemni aspekty otrymannia vyshchoi osvity v Ukraini zhestomovnymy hluhymy osobamy / N. B. Adamiuk. - Zbirnyk naukovykh prats «Pedahohichni nauky». Vypusk LXXXIII. - Tom 1, Khersonskyi derzhavnyi universytet, vydavnychyi dim «Helvetyka», 2018. S.194-202.

6. Adamiuk N. B. Suchasnyi pohliad na zhectovu movu / N. B. Adamiuk. - Osvita osib z osoblybymy potrebamy: shliakhy rozbudovy: zb. nauk. prats: Vyp. 14/ za red. V. V. Zasenka, A. A. Kolupaievoi. - 2018. - S. 11-20. 